\title{
Thai amber: insights into early diatom history?
}

\author{
Vincent Girard ${ }^{1, *}$, Simona Saint Martin ${ }^{2}$, Eric Buffetaut ${ }^{3,8}$, Jean-Paul Saint Martin ${ }^{2}$, Didier Néraudeau ${ }^{4}$, \\ Daniel Peyrot ${ }^{5}$, Guido Roghi ${ }^{6}$, Eugenio Ragazzi ${ }^{7}$ and Varavudh Suteethorn ${ }^{8}$ \\ ${ }^{1}$ Institut des Sciences de L'Évolution de Montpellier, UMR CNRS 5554, Place Eugène Bataillon, 34095 Montpellier, France \\ 2 CR2P UMR 7207, MNHN-SU-CNRS, 8, rue Buffon, F75005 Paris, France \\ ${ }^{3}$ Laboratoire de Géologie de l'École Normale Supérieure, UMR CNRS 8538, PSL Research University, 24, rue Lhomond, F75013 Paris, \\ France \\ ${ }^{4}$ Laboratoire Géosciences Rennes, Université de Rennes 1, UMR CNRS 6118, 263, Avenue du Général Leclerc, F30042 Rennes, France \\ 5 School of Earth and Environment, University of Western Australia, 6101 Crawley, Western Australia \\ ${ }^{6}$ Institute of Geosciences and Earth Resources (IGG-CNR), Via Gradenigo, 6, I35131 Padova, Italy \\ ${ }^{7}$ Department of Pharmaceutical and Pharmacological Sciences, University of Padua, Largo E. Meneghetti 2, I35131 Padova, Italy \\ ${ }^{8}$ Palaeontological Research and Education Centre, Maha Sarakham University, Khamrieng Sub-district, Kantharawichai District, Maha \\ Sarakham Province 44150, Thailand
}

Received: 29 August 2019 / Accepted: 28 June 2020

\begin{abstract}
The origin of the diatoms still remains enigmatic. Their fossil record is scarce until the Late Cretaceous and great divergences exist between molecular data and the earliest fossil evidence. While molecular data indicate an origin during the Triassic or Early Jurassic, early fossil evidence is only from the Late Jurassic-Early Cretaceous. The discovery of diatoms in French mid-Cretaceous amber by the end of the 2000 s already suggested a potential bias in the diatom fossil record as it made older many diatom lineages, the record of which hitherto began at the end of the Cretaceous. The Jurassic/Early Cretaceous fossil record of diatoms is extremely sparse and any new occurrence is important for retracing the evolutionary, palaeogeographical and palaeoenvironmental history of diatoms. Thai amber has yielded a new diatom specimen that has been attributed to the genus Hemiaulus. Fossil assemblages and sedimentological data indicate that Thai amber and its Hemiaulus specimen are Late Jurassic in age. This discovery represents the oldest hitherto known specimen of Hemiaulus and so extends the fossil record of the bipolar diatoms and of the genus Hemiaulus by several dozens of millions of years and brings closer the fossil evidence and molecular data (that estimated an origin of the bipolar diatoms about $150 \mathrm{Ma}$ ago). It reinforces the hypothesis of a pre-Cretaceous fossil diatom records and also supports an origin of the diatoms in shallow coastal environments.
\end{abstract}

Keywords: Fossil resin / Mesozoic / Bacillariophyta / Origin / Shallow marine environments

Résumé - L'ambre de Thaïlande : une fenêtre sur l'histoire des premières diatomées ? L'origine des diatomées reste toujours énigmatique. Leur registre fossile est rare jusqu'au Crétacé supérieur et il existe de grandes différences entre les données moléculaires et les premières évidences fossiles du groupe. Tandis que les données moléculaires indiquent une origine durant le Trias ou le Jurassique inférieur, les plus anciennes traces fossiles sont seulement de la fin du Jurassique, début du Crétacé. La découverte de diatomées dans l'ambre médio-crétacé français à la fin des années 2000 avait déjà suggéré un potentiel biais dans le registre fossile des diatomées car cela vieillissait plusieurs lignées précédemment connues uniquement à partir du Crétacé supérieur. Le registre fossile des diatomées du Jurassique et du Crétacé inférieur est extrêmement limité et toute nouvelle occurrence est importante pour retracer l'histoire évolutive, paléogéographique et paléoenvironnementale des diatomées. L'ambre de Thaïlande a permis la découverte d'un nouveau spécimen de diatomée attribué au genre Hemiaulus. Les données paléontologiques et sédimentologiques attestent que l'ambre thaïlandais et la diatomée qu'il contient sont d'âge Jurassique supérieur. Cette

*Corresponding author: vincent.girard@umontpellier.fr 
découverte représente le plus ancien spécimen du genre Hemiaulus connu à présent et étend donc le registre fossile des diatomées bipolaires et du genre Hemiaulus de plusieurs dizaines de millions d'années et rapproche ainsi le registre fossile des données moléculaires (qui estimaient l'origine des diatomées bipolaires à environ 150 millions d'années). Cela renforce l'hypothèse d'un registre fossile pré-crétacé et soutient une origine des diatomées au sein d'environnements marins néritiques.

Mots clés : Résine fossile / Mésozoïque / Bacillariophyceae / Origine / Environnements marins peu profonds

\section{Introduction}

Diatoms (Bacillariophyta) represent an extremely diverse and successful lineage of photosynthetic Stramenopiles (Chromalveolates) with a siliceous cell wall. They are one of the most important groups of primary producers in modern ecosystems (Kooistra et al., 2007); they have colonized both marine and freshwater environments and are important agents in the global biosynthesis of organic matter (Kooistra et al., 2007). They have a great impact on carbon cycling (Smetacek, 1999; Falkowski et al., 2004) and play a key role in the biogeochemical cycle of silica (Tréguer et al., 1995). Apart from their significance for modern ecosystems, the origin of diatoms is still enigmatic (Falkowski et al., 2004). Molecular clock estimates suggest an origin at ca. $240 \mathrm{Ma}$, during the Triassic (Sorhannus, 2007) or, following Medlin (2011), a root of the diatom lineage is constrained between 250 and $190 \mathrm{Ma}$. Recently, Nakov et al. (2018) estimated the diatom crown age at $190.4 \mathrm{Ma}$ and thus placed the origin of diatoms near the Triassic-Jurassic boundary.

The oldest available estimates are based on a 19th century record from the Early Jurassic of Germany (Rothpletz, 1896). However Rothpletz's material has been lost and thus cannot be studied again to verify its position within the Bacillariophyta (Harwood et al., 2007). Serious doubts exist also about the age of Rothpletz's material. Some microfossils from the German diatomaceous sediments were studied by Rüst (1885). Kemper et al. (1975) reviewed Rüst's illustrations and referred the sediments (and therefore the diatoms) to the Early Cretaceous. In fact the known biostratigraphic distribution of diatoms indicates that their fossil record is very scarce until the Late Cretaceous (Harwood et al., 2007). Diatom resting spores have been found in the Lower Cretaceous of Korea (Harwood et al., 2007; Chang et al., 2007), but the first well-preserved fossils of unequivocal vegetative cells and resting spores are known from Lower Cretaceous marine deposits of Antarctica; they were originally dated as late Aptian-early Albian (Gersonde and Harwood, 1990; Harwood and Gersonde, 1990), but they were recently reconsidered to be early to midAlbian in age (McCartney et al., 2014). Coeval fossils from Australia and Germany suggest that diatoms had already a broad distribution in marine environments by the end of the Early Cretaceous (Harwood et al., 2007). This is confirmed by Albian and later fossil records of diatoms. During and after the Albian, deposits with fossil diatoms become more numerous, from Russia (Jousé, 1949; Strel'Nikova and Martirosjan, 1981), Canada (Wall, 1975), Germany (Forti and Schulz, 1932; Georgi, 1976) and Italy (Foucault et al., 1986). These findings show that diatoms already had a worldwide distribution by the Albian.

One drawback of the Cretaceous fossil record of diatoms is their pyritized preservation, which obscures morphological features (Girard et al., 2009b). Diatoms were rare in nonmarine environments before the Maastrichtian (Chacón-Baca et al., 2002) and they did not become abundant until the Eocene (Sims et al., 2006).

Here we report a unique diatom specimen preserved in amber from the Upper Jurassic of Thailand. This specimen provides a new case of diatom preservation in amber and new insights into early diatom history, both in terms of evolutionary history and palaeogeographical origin.

\section{Material and Methods}

\subsection{Geological and palaeoenvironmental settings}

The amber originates from the Khlong Min Formation, in Southern Peninsular Thailand (Philippe et al., 2005). It is found in non-marine sediments, the stratigraphy of which has been reviewed by Teerarungsigul et al. (1999). The Klong Min Formation is the basal part of the Trang Group that corresponds to clastic sediments (Philippe et al., 2005). Philippe et al. (2005) indicated that the amber site does not provide marine fossils. These authors described the stratigraphy of the amber site as follows, from bottom to top:

- Layer 1: calcareous sandstones in which large lignitic trunks are preserved. Other plant debris are rarer, even though smaller woody axes (branches and roots) have been found in these sandstones. Philippe et al. (2005) interpreted these sediments as fluvial deposits.

- Layer 2: lenticular clayey silts that contain abundant amber nodules, conifer leafy twigs, lignite and charcoal. On the basis of the taphonomic characteristics of the fossils, Philippe et al. (2005) interpreted this assemblage as parautochthonous and deposited on a lake margin.

- Layer 3: calcareous conglomerate that contains a few plant remains such as rounded charcoal pieces, very small amber fragments and calcitised wood pebbles. Philippe et al. (2005) interpreted it as high-energy fluvial deposits.

Philippe et al. (2005) analysed the fossil wood specimens from the amber site. All correspond to conifers and the most interesting finding was the discovery of a 5 -cm-long amber nodule filling a crack within wood of Agathoxylon Hartig. It suggests that Auracariaceae and/or Cherolepidiaceae have produced Thai amber.

\subsection{Age of the Khlong Min Formation}

Asama et al. (1981) were the first to date the Klong Mon Formation and they suggest an Early Cretaceous age on the basis of the study of the palaeoflora, especially because of the presence of the conifer Frenelopsis only known from the 


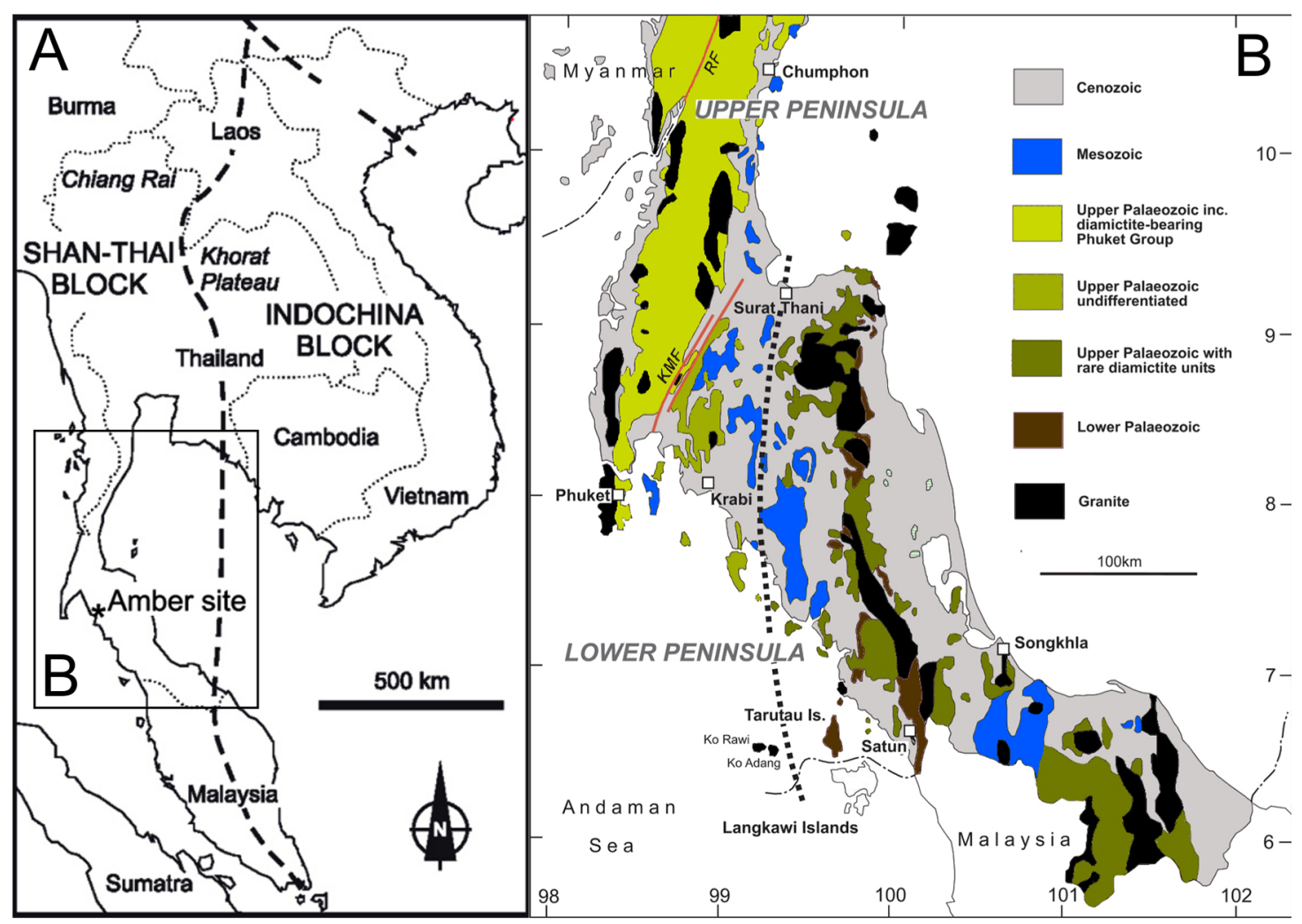

Fig. 1. Location map of Late Jurassic/Early Cretaceous amber outcrop of Thailand.

Cretaceous. However Philippe et al. (2005), reviewing the illustrations given by Asama et al. (1981), noticed that the fossils look more like the genus Cupressinocladus that is known from the Jurassic to the Cretaceous.

On the basis of a palynological study, Lei (1993) attributed a Jurassic age to the formation. More precisely, he suggested a Late Jurassic age because of the high percentage of Classopollis, although Vakhrameev (1987) had demonstrated that the percentage of Classopollis is an inverse factor of latitude and cannot be used for dating. Racey and Goodall (2009) revised the data of Lei (1993) and they suggested that the age of the Khlong Min Formation was not younger than Cenomanian. However these authors did not clearly indicate which part of the Khlong Min Formation their samples came from.

From a palaeontological point of view, all other authors considered the Khlong Min Formation as Jurassic in age. Chongllakmani and Duan (1990), on the basis of conchostreans suppose a late Middle Jurassic age. The presence of a sauropod originally referred to the Euhelopodidae (Buffetaut et al., 2005) and now placed in the Mamenchisauridae (Suteethorn et al., 2012) suggests a probable Late Jurassic age. Similarly, according to Philippe et al. (2005) the presence of Asteracanthus teeth is consistent with a Jurassic age because this genus is regionally known from Late Jurassic deposits (Fontaine, 1990). Cuny et al. (2009) indicated that the elasmobranch assemblage indicates a late Middle Jurassic age for the lower part of the Khlong Min Formation. Saengsrichan et al. (2011) mentioned the presence of Parvamussium donaiense Mansuy, 1914, a Jurassic bivalve, that is found up to the top of the Khlong Min Formation, suggesting that it is really Jurassic in age. According to Cuny et al. (2014) concerning the shark faunas of northeastern Thailand, a Bathonian-Callovian age is considered for the Khlong Min Formation. Focused on thalattosuchian crocodylomorphs, recent works assign the Khlong Min Formation to the Late Jurassic (Martin et al., 2016) and more precisely to the Bathonian-Callovian (Martin et al., 2019).

From a geological point of view, the Khlong Min Formation is part of the Late Jurassic sedimentary series. Meesook and Saengsrichan (2011), in their synthesis of the Mesozoic of Thailand, attributed the Khlong Min Formation to the Middle Jurassic and they interpreted it as a gradual change from lagoonal to lacustrine deposits. According to Kanjanapayont (2014) the regressive trend continues during the Jurassic up to the upper Khlong Min Formation (Fig. 1).

It is clear from all this that the Khlong Min Formation is better considered as Jurassic in age, with some authors even specifying a Bathonian-Callovian age. Such an assumption is accepted in the recent review by Seyfullah et al. (2018) that indicates a Mid-Late Jurassic age for the amber of the Khlong Min Formation.

\subsection{The amber}

According to Philippe et al. (2005) the Thai amber is represented by abundant flattened nodules, that can reach $3 \mathrm{~cm}$ in diameter, occurring within clays (Layer 2 described above). The amber pieces are clear and exhibit a yellow-brown colour. Philippe et al. (2005) indicated that Thai amber is strawcoloured and not oxidised. The general aspect of Thai amber suggests that amber was not modified by any tectonic and/or 
volcanic activities and remains in its primary shape, contrary to amber pieces that suffered metamorphic and/or volcanic alteration such as the amber piece described by Girard et al. (2014).

\subsection{Optical observations}

Amber samples were initially investigated under a standard stereomicroscope. Possible contamination was ruled out following the three-step chemical protocol described in Girard et al. (2009a). Samples were broken in order to obtain smaller pieces in which different characteristics of the fossils were easily visible. This step was done several times to obtain the smallest fragments that were then mounted on a slide with Canada balsam and observed. The amber samples were then investigated and photographed under a Leica DMLP microscope.

\subsection{Thermal analysis}

Thermogravimetric analysis of Thai amber was performed according to a previously described method (Ragazzi et al., 2003). The thermogravimetric (Differential Thermo-Gravimetric, DTG) curves were obtained from three samples from Thai amber. According to published data (see Ragazzi et al., 2003, 2009 for more details), a progressive change of the major thermal event is correlated to the age of the sample. The thermal analysis can therefore be used to estimate the age of the resin, in addition to other dating methods. Linear regressions through main thermal peak data available in our laboratory (for more information, contact two of us: GR and ER) and obtained from resins of different geological ages and origin (Ragazzi et al., 2003, 2009) permitted to compare the thermal behavior data of the Thai amber samples. Different linear regression models were used to estimate the age of our samples.

\section{Results}

\subsection{The diatom Thai specimen (Fig. 2)}

A single specimen of bipolar diatom has been found in the amber sample KM01. Due to the presence of impurities in amber, the specimen is difficult to access. The characters present on the Thai diatom (such as a bipolar frustule, an elliptical valve with long polar elevations) indicate that the specimen belongs to the Hemiaulaceae Heiberg 1863 and more precisely to the genus Hemiaulus Heiberg 1863, according to generic characters from Hasle and Syvertsen (1997). The absence of more detailed features makes hazardous an assignment to the species level.

Here we present the description of the Thai diatom, using the classification presented by Guiry and Guiry (2020) from AlgaeBase.

Class Mediophyceae Medlin and Kaczmarska, 2004

Subclass Chaetocerotophycidae Round and R.M. Crawford, 1990

Order Hemiaulales Round and R.M. Crawford, 1990

Family Hemiaulaceae Heiberg 1863

Genus Hemiaulus Heiberg 1863

Hemiaulus sp.
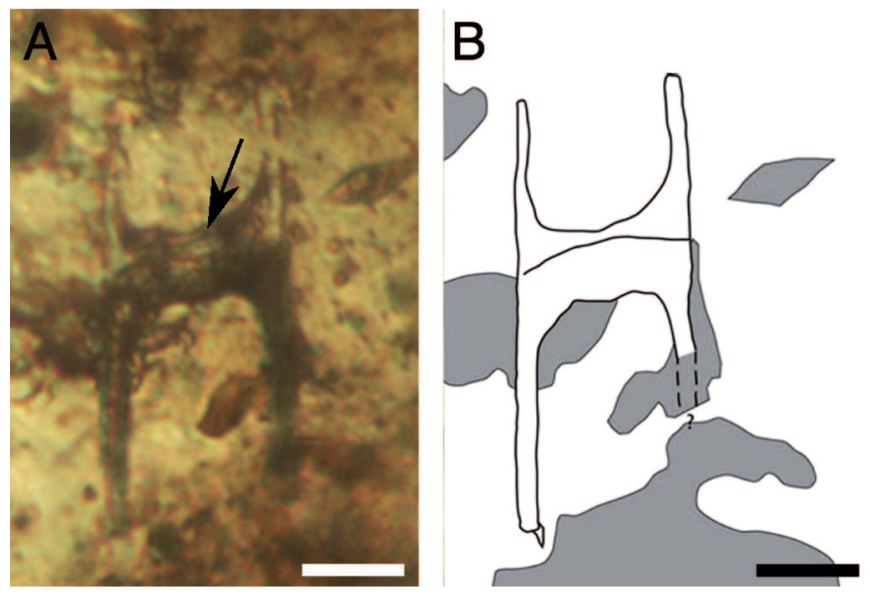

Fig. 2. The Hemiaulus diatom found in Late Jurassic-Early Cretaceous amber from Thailand. A. Photograph of specimen within dark amber matrix. B. Interpretative drawing of the photograph. Scale bar represents $10 \mu \mathrm{m}$. We can clearly distinguish the central parts of the frustule and its typical elevations. They end with spines corresponding to the linking apparatus of the frustule. The black arrow on $\mathrm{A}$ indicates the hyaline marginal ridge.

The specimen has subrectangular valves in girdle view with two long straight elevations ( $34 \mu \mathrm{m}$ long) parallel to the pervalvar axis at the ends of the apical axis. Elevations exceed the valve length. Elevations seem to become very slightly narrower in their upper part. The ends of the elevations are not all visible. One of these polar elevations exhibits an apical spine ( $3 \mu \mathrm{m}$ long) that represents the linking apparatus of the diatom. The girdle view allows to distinguish the hypovalve (the upper part of the specimen) and the epivalve (the lower part of the specimen). Thanks to small variations in the orientation of the microscopic slide and in the depth of observations within the amber, it seems that the specimen has an elliptical valve outline even though it has never been possible to confirm it with a clear observation of the valve view. Due to the mode of preservation, only the valve length along the apical axis was measured ( $45 \mu \mathrm{m}$ long). The curvature of the valve face was not possible to be determined. It seems that two transapical pseudoseptae delimit a central segment. Unfortunately we were not able to observe whether there is a labiate process in the centre of the central segment. The valve mantle is not deep. Areolae are visible on the valve mantle and on the polar elevations. However due to the mode of preservation of the specimen, it has not been possible to clearly access this character. No clear pattern in the organization of the areolae is visible. A hyaline marginal ridge mostly visible on the hypovalve surrounds the valve face and seems to connect the two elevations.

Remarks: We attribute the Thai specimen to Hemiaulus since we observed typical characteristics of the genus that distinguish it from other similar looking genera with "hemiauloid" valves, such as Cortinocornus and Riedelia. The Thai specimen shows a general aspect of the valve similar to Cortinocornus, a genus common in Late Cretaceous assemblages from Devon Island, Canadian Arctic as mentioned by Tapia and Harwood (2002) and Witkowski et al. (2011) and also in the Upper Cretaceous of Saratov region (Oreshkina 

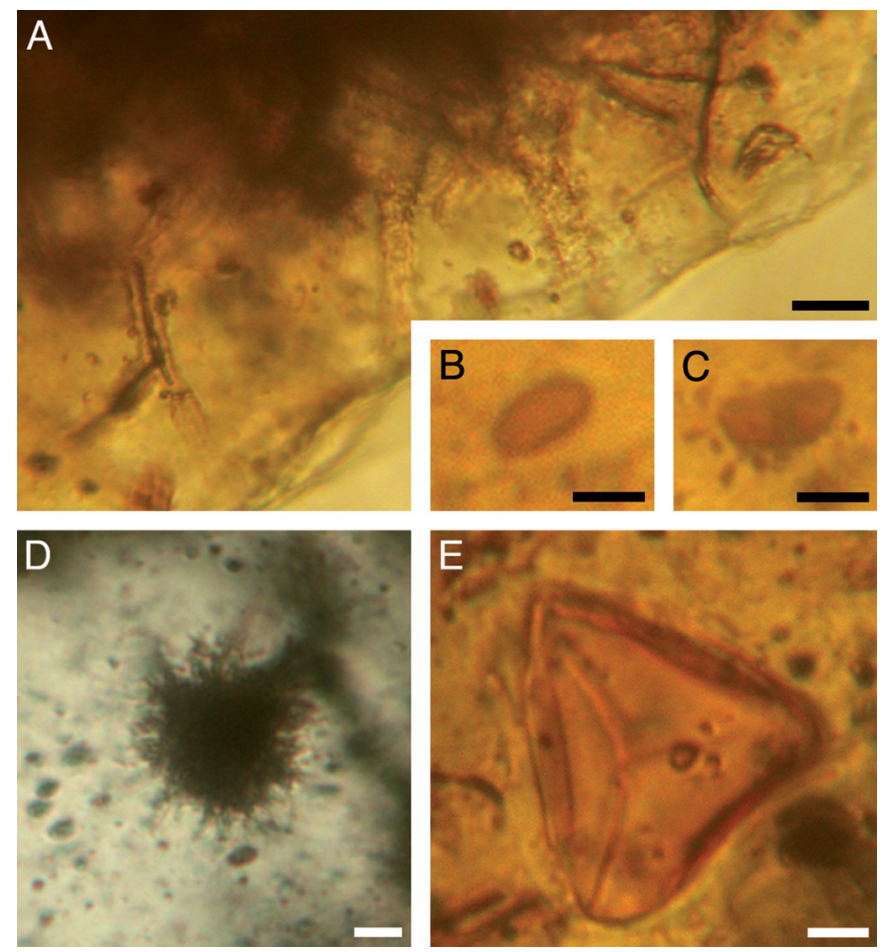

Fig. 3. Microfossils found in amber from Thailand. A. Sheathed prokaryotes. Scale bar: $20 \mu \mathrm{m}$. B. Single fungal spore. Scale bar: $5 \mu \mathrm{m}$. C. Fungal Didymospore. Scale bar: $5 \mu \mathrm{m}$. D. Colony of unidentified actinomycete. Scale bar: $10 \mu \mathrm{m}$. E. Spore of the pteridophyte genus Gleicheniidites. Scale bar: $10 \mu \mathrm{m}$.

et al., 2013) and the Paleogene of Central Russia, Transuralia (Oreshkina and Radionova, 2014). The main difference between the two genera consists in the presence of spines on elevations in Hemiaulus, while Cortinocornus does not possess this character.

Riedelia is a fossil genus containing species originally described under the genus Hemiaulus mainly from the DSDP Leg 38 (Schrader and Fenner, 1976). Riedelia valves are punctate with isolated punctae, while Hemiaulus has polygonal areolated valves. Moreover, Riedelia has two spines on each elevation, while Hemiaulus has only one. Also, the absence of any pseudoseptae is typical for Riedelia. In our specimen from Thai amber, the presence of areolae on the valve, a single spine on each elevation and transapical pseudoseptae supports the placement of the specimen in the genus Hemiaulus.

\subsection{Amber syninclusions}

The single specimen is in close proximity to fragments of either decayed organic matter or spherical to ovoid microinclusions in a very dark part of the amber.

The diatom was found with other syninclusions of which the most abundant are sheathed prokaryotes (Fig. 3A). They are composed of a trichome, $1 \mu \mathrm{m}$ thick surrounded by a translucent sheath, 5-8 $\mu \mathrm{m}$ in diameter. These microinclusions are very similar to those described in many Cretaceous ambers (see review and discussion in Saint Martin and Saint Martin, 2018). Whatever their real nature, this is the oldest known occurrence of this type of resinicolous microorganisms. Two different spores of fungi have also been identified. The first one consists of a single ovoid cell (Fig. 3B), the second corresponds to a didymospore (Fig. 3C). Colonies of unidentified actinomycetes were also observed (Fig. 3D). A spore belonging to the genus Gleicheniidites Ross ex Delcourt and Sprumont 1955 (Pteridophyta) was also found (Fig. 3E).

\subsection{Thermal analysis}

The main exothermal event (indicating the highest rate of weight loss under controlled heating) evidenced by a main thermal peak (MaTHEP), ranged between 425 and $435^{\circ} \mathrm{C}$ (Fig. 4). Additional peaks, indicating further exothermal events, occurred at $470{ }^{\circ} \mathrm{C}$ and at $568-590^{\circ} \mathrm{C}$.

Linear regressions through main thermal peak data provided the possibility to calculate a theoretical age for this amber (Tab. 1). Considering a first linear model (where $x$ axis is MaTHEP in ${ }^{\circ} \mathrm{C}$, and $y$ axis is age in Ma) it was possible to obtain, through a linear regression, an age estimate of the samples in the range 104-118 Ma (corresponding to the Lower Cretaceous-Albian) (Fig. 5A). Using another linear regression model (where $x$ axis is age, and $y$ axis is MaTHEP), a higher estimate was obtained, ranging 124-165 Ma (Fig. 5B). It may be noted that the slope of this line is mainly affected by the data apparently being outliers, and therefore the values obtained may be overestimated. The use of a robust linear regression however did not modify the values obtained with a regular linear model estimate. Moreover, the variability of thermal peaks observed in analysed Thai amber suggests that there is probably a different resin maturation profile among specimens, that can affect the age estimate. Thermal analysis of amber cannot be considered an unbiased method for amber estimation, but a complementary method to other age estimates, as suggested by the above cited palaeontological and geological investigations.

\section{Discussion}

\subsection{Thai amber age}

The thermal analysis was used to have a rough estimate of the age of the resin as described in Ragazzi et al. (2003), assuming a proportional relationship between the temperature of the main exothermal event and the age of the resin. Because of the different peaks and mathematical models, the analysis revealed contradictory estimated ages varying from 165 to $104 \mathrm{Ma}$. These new results however suggests that Khlong Min amber could be Late Jurassic-Early Cretaceous in age. Comparing it to all previous data published on the age of the Formation (see above), it is possible to suggest that Khlong Min amber is Late Jurassic in age.

\subsection{Amber forest palaeoecology}

The fragments of decayed organic matter and the spherical to ovoid microinclusions in the very dark parts of the amber are similar to some microinclusions described by Girard et al. (2011) in honey and yellow ambers from Charentes (France). Girard (2010) and Girard et al. (2011) interpreted such kinds of 
THAI 1

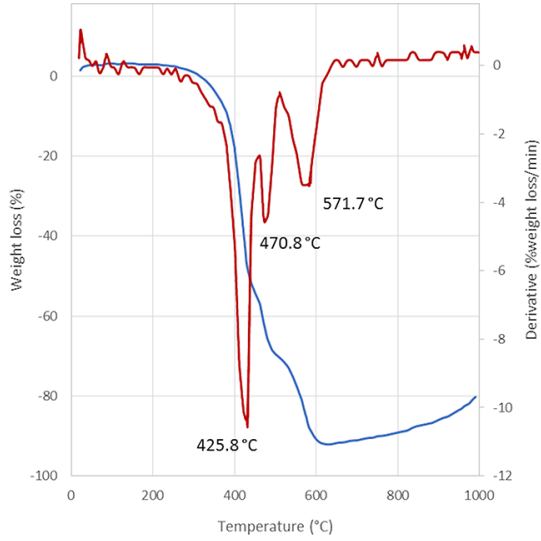

THAI 2

THAI 3

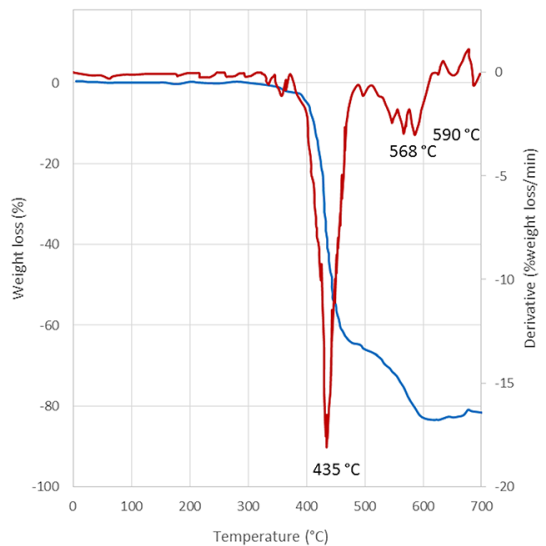

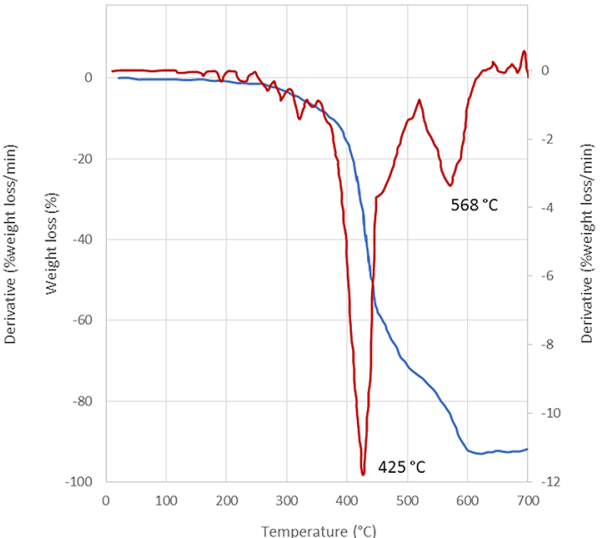

Fig. 4. Thermogravimetric curves obtained with three samples of Thailand amber. Thick line indicates the DTG profile; thin line is the TG profile (see Ragazzi et al., 2003, 2009 for details).

Table 1. Age estimation of the Thai amber by thermogravimetric analyses.

\begin{tabular}{llll}
\hline Sample & Main DTG peak (MaTHEP, $\left.{ }^{\circ} \mathrm{C}\right)$ & Age estimation $(\mathrm{Ma})$, model 1 & Age estimation $(\mathrm{Ma})$, model 2 \\
\hline Thai1 & 425.8 & 105 & 127 \\
Thai2 & 425 & 104 & 124 \\
Thai3 & 435 & 118 & 165 \\
\hline
\end{tabular}

SOM1: Full list of MaTHEP data of fossil resins used for the thermogravimetry method.

Age $(\mathrm{Ma})=-464.361+1.338^{*}$ Main DTG peak $\left({ }^{\circ} \mathrm{C}\right)$

A

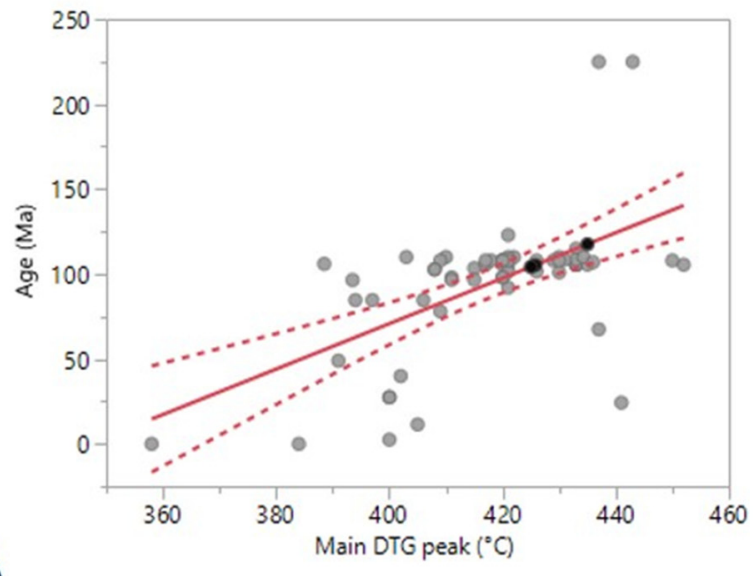

Fig. 5. Bivariate fit of Age versus MaTHEP (Main DTG peak, ${ }^{\circ} \mathrm{C}$ ) for several data available in our database, obtained from samples of amber of different ages, indicated as grey circles. A significant correlation coefficient $(r=0.5730, p<0.0001)$ was obtained throughout the overall dataset. Black points along the regression line indicate the three samples of Thai amber. As the dependent variable, MaTHEP was considered in panel on the left (A), and Age in the panel on the right (B); respective equations obtained with standard least squares method are indicated above each graph. Complete list of data for regression is provided as supplementary information.

amber as probable aerial secretions on the trunk and branches of the resiniferous trees.

The scarcity of syninclusions in Thai amber does not allow to reconstruct with much precision the amber forest ecology.
Main DTG peak $\left({ }^{\circ} \mathrm{C}\right)=394.607+0.245^{\star}$ Age $(\mathrm{Ma})$

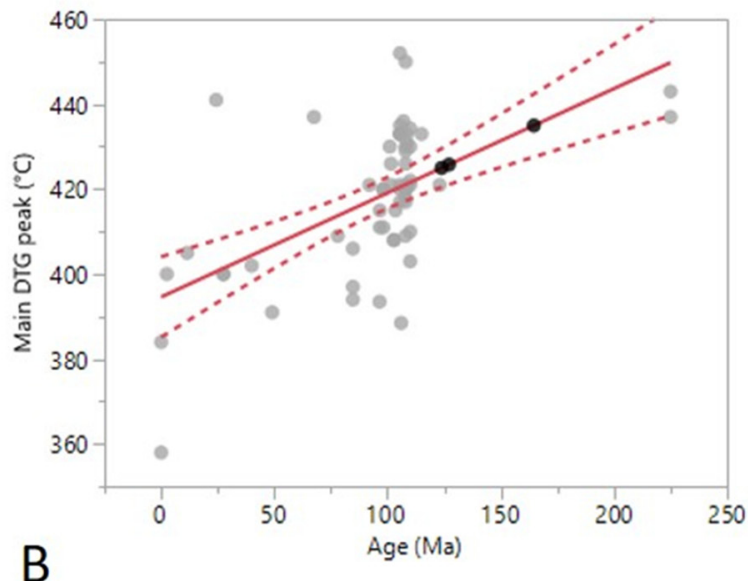

The presence of bacterial filaments in Thai amber, developed in some pieces of amber as dense networks of filaments, can indicate that Thai amber had been secreted in a humid environment. Such a hypothesis is in agreement with Philippe 
et al. (2005) who interpreted the fossils from the amberbearing clayey silts as parautochthonous and the depositional environment as the margin of a lake. The presence of a fern spore in Thai amber also supported this hypothesis. Its discovery is remarkable because pollen and spores are relatively rare in Mesozoic amber. Gleicheniidites spores were already found in Mesozoic Thai sediments (Racey and Goodall, 2009). The presence of a spore in Thai amber suggests that resiniferous conifers and Gleicheniidaceae ferns grew together in the Jurassic vegetations. It is highly probable that ferns formed the undergrowth of the Thai conifer forests. The presence of fungal spores also corroborates the hypothesis of the resiniferous forests growing in a humid or close to a humid environment. The presence of a marine diatom in Thai amber indicates that the amber forests grew close to the sea. The interpretation of Philippe et al. (2005) considering the depositional environment as the margin of a lake can thus be revised: it was as a seashore rather a lakeshore.

\subsection{Stratigraphic range of bipolar diatoms and Hemiaulus}

Based on molecular data supported by morphological and cytological characteristics, the Clade 1 and Clades $2 \mathrm{a}$ and $2 \mathrm{~b}$ proposed by Medlin and Kaczmarska (2004) are recognized (Sims et al., 2006; Medlin, 2011) at class level: Coscinodiscophyceae containing centric diatoms with radial symmetry of valve shape and structure; Mediophyceae containing the bior multipolar centrics and the radial Thalassiosirales; Bacillariophyceae containing the pennates.

The genus Hemiaulus, because of its bipolar shape in valve view, is included in Mediophyceae within the bipolar centrics.

Sorhannus (2007), based on nuclear-encoded SSU rRNA analyses, estimated the divergence of bipolar centric diatoms at $150 \mathrm{Ma}$ ago. Medlin (2010) and Sato (2008) found much older divergence times for all the classes. Their clock suggests that the radial centrics, Class Coscinodiscophyceae, arose from 180 to $240 \mathrm{Ma}$ ago and the bipolar centrics, Class Mediophyceae diverged from the Class Bacillariophyceae at $183-238 \mathrm{Ma}$ (minimum to maximum, respectively). However, fossil records of bipolar diatoms still do not agree with this estimate. Up to know the oldest fossil evidence of bipolar diatoms came from Aptian/Albian sediments of the Weddell Sea (Antarctica) where Gersonde and Harwood (1990) found Bilingua rossii Gersonde and Harwood 1990 and Kerkis bispinosa Gersonde and Harwood 1990. Slightly younger (Late Albian) is the diverse assemblage of marine diatoms from the amber of Charentes (Girard et al., 2008, 2009b). It comprises many specimens attributed to the genus Hemiaulus and one specimen of Rutilaria, named Syndetocystis in Girard et al. (2008) and revised by Witkowski et al. (2011). These assemblages testify to a very long stratigraphic range (100 million years) for Hemiaulus.

Before these discoveries, the divergences between molecular data and the fossil records of different families were greater. Indeed, the Hemiaulaceae, more precisely the genus Hemiaulus, were first found in Early Late Cretaceous marine sediments (Tapia and Harwood, 2002), before becoming more abundant and diverse into Upper Cretaceous deposits (Strel'Nikova, 1975; Jousé, 1978; Oreshkina et al., 2013). During the Cenozoic, they become very abundant, with some species such as some included in the genus Hemiaulus that have been used as stratigraphic markers (Barron and Baldauf, 1995). Extant Hemiaulus comprises only four species.

The Thai specimen extends the stratigraphic range of the genus Hemiaulus to the Late Jurassic, making Hemiaulus the diatom genus with the longest stratigraphic range ever found. According to molecular dating (Sorhannus, 2007), the Thai specimen provides geological evidence for the occurrence of Hemiaulus soon after the origin of bi- and multipolar diatoms. The recent time calibrated phylogeny of diatoms published by Nakov et al. (2018) indicates a minimum age for the emergence of Hemiaulus at ca. $130 \mathrm{Ma}$, and the age of the emergence of the clade containing Hemiaulus and Chaetoceros between $150 \sim 100 \mathrm{Ma}$. Our discovery of a Hemiaulus specimen in amber dated from the Late Jurassic agrees quite well with the results of this new diatom evolutionary tree. Therefore, the Thai specimen also extends the fossil record of the hemiauloids in particular and consequently that of bipolar diatoms.

Other bipolar diatoms, the Rutilariaceae, seem to originate from the Late Cretaceous (Witkowski et al., 2011). Only the possible specimen of Rutilaria found in French amber (Girard et al., 2008) makes this family older. Hemiaulus from Thai amber supports the supposition of Ross (1995) followed by Witkowski et al. (2011), who considers the Hemiaulaceae as ancestral to the Rutilariaceae.

The Thai diatom corroborates the estimation proposed by Sorhannus (2007) and confirms the hypothesis of an origin of the bi- and multipolar diatoms by the end of the Jurassic/ beginning of the Cretaceous.

No other evidence of Jurassic diatoms is known, except the problematic Liassic German specimens of Pyxidicula (Rothpletz, 1896, 1900) as mentioned above.

The discovery of fossil diatoms in amber from Charentes (Girard et al., 2008, 2009b) and Vendée (Saint Martin et al., 2015) already showed that this specific preservation of diatoms provides important data that bring new insights into our knowledge of the early fossil record of diatoms. The Thai specimen reinforces the state of the art and should stimulate active researches on Jurassic to Early Cretaceous ambers. Mesozoic ambers from the Triassic of Italy (Roghi et al., 2006, 2017), Jurassic amber localities in Lebanon (Nohra et al., 2013) and mid Cretaceous Burmese amber (Yu et al., 2019) could be good candidates.

\subsection{Long ranging Hemiaulus: palaeogeographical and palaeoecological implications}

As discussed above, the discovery of Hemiaulus in Late Jurassic Thai amber reveals the persistence of the genus from ca 145-160 million years ago to the present. Long morphological stases were already mentioned for some protists, especially based on amber inclusions (Martín-González et al., 2008). These possible stases have been mostly observed in green algae and amoebae. For example the Cenomanian Schliersee amber preserved six different green algae, an euglena, two fungi and sixteen amoebae (Poinar et al., 1993a, 1993b; Schönborn et al., 1999; Dörfelt and Schäfer, 2000, Schmidt et al., 2004). Among all these fossils, 19 taxa have 
been related to modern genera, and in some cases, to modern species. A long stratigraphic range for the diatom genus Hemiaulus can appear remarkable for a group of organisms known to have rapid evolutionary rates (Bowler et al., 2008). However, Wornardt (1972) and Jousé (1978) already mentioned 11 and respectively 7 genera including Hemiaulus that are known from the Cretaceous to the Present Day.

Thus the genus Hemiaulus has been present since the beginning of the Mediophyceae, survived different extinction events such as that of the Cenomanian/Turonian boundary (Harwood et al., 2007) and experienced several major periods of floral turnover during the Cenozoic, such as that of the Middle Eocene-early Oligocene (Baldauf, 1992).

The oldest known occurrence of Hemiaulus (present study) comes from a low latitude neritic coastal context. Early Late Cretaceous Hemiaulus from French amber (Charentes) corresponds to mid-latitude coastal environments (Girard et al., 2008, Girard et al., 2009a, 2009b; Girard, 2010). This is consistent with the observation of Jewson and Harwood (2017), who suggested that Early Cretaceous diatoms were restricted to continental margins. Late Cretaceous diatom assemblages (including Hemiaulus) are known from extensive diatomites developed in different geographical zones: the eastern Urals and north-western Siberia (e.g. Strel'Nikova, 1975), the Marca Shale, Moreno Formation in California (e.g. Hanna, 1927; Nikolaev et al., 2001) and also in sediments from Antarctica (Harwood, 1988), Arctic Canada (Tapia and Harwood, 2002; Witkowski et al., 2011) associated with a deposition in a shallow nearshore habitat. Other occurrences come from diatomaceous sediments recorded in the Pacific Ocean deep-sea drilling core Site 275 (Hajos and Stradner, 1975), Indian Ocean, site 758 (Fourtanier 1991a), Arctic Ocean, Core FI-437 Alpha Ridge (Dell'Agnese and Clark, 1994), CESAR core 6, Arctic Ocean (Barron, 1985). In Arctic sites Hemiaulus was found in associations with resting spores, benthic and neritic species suggesting a shallow water environment (Harwood, 1988). Poor diatom occurrences or with pyritized diatoms are also known from the Lower and Upper Cretaceous (see list in Tapia and Harwood, 2002)

Paleocene occurrences of Hemiaulus come from extensive biosiliceous sediments in land section and also from profiles recovered by successive Deep Sea Drilling Projects. Diatom assemblages including Hemiaulus are known mainly from the Russian Platform in a context of epicontinental shallow sea basins (for reviews of the sites see Jousé, 1978, Oreshkina and Radionova, 2014), from the Fur Formation, Denmark (Homann, 1991; Fenner, 1994) and Seymour Island, Antarctica (Harwood, 1988). Hemiaulus is recorded from several deep-sea drilling cores from the Atlantic, Pacific and Indian Oceans (for lists of sites see Fourtanier, 1991b; Renaudie et al., 2018). During the Paleocene Hemiaulus was represented by a plethora of species and had a geographic distribution in both the southern and northern hemispheres, both in epicontinental seas and in more open oceanic environments.

Eocene Hemiaulus occurrences are documented in onshore sections of the Fur Formation (Moler Formation) in Denmark (Benda, 1972; Fenner, 1988), in the Urals, western Siberia, the Volga basin, Ukraine, south Kazahstan (see review in Oreshkina and Radionova 2014), the Kellog Shale, California (Barron et al., 1984), lower part of Oceanic formation of
Barbados and Oamaru, New Zealand (Edwards, 1991) and also from deep-sea drilling cores from the Atlantic, Pacific and Indian Oceans, the Norwegian Sea (for lists of sites see Fourtanier, 1991b; Barron et al., 2015). Distinct latitudinal diatom assemblages with distinct Hemiaulus species were identified for high and middle low latitudes and for low latitudes respectively together with cosmopolitan species (Fenner, 1985). As in the Paleocene, Hemiaulus persists among the dominant genera within diatom assemblages corresponding either to epicontinental seas, or more open oceanic environments.

Oligocene Hemiaulus is documented from different deepsea drilling cores both at high (e.g. Schrader and Fenner, 1976; Monjanel, 1987; Scherer et al., 2000) and low latitudes (e.g. Barron, 1985; Fenner, 1985). A major change concerning Hemiaulus diversity begins with the middle Oligocene when most of the typical Eocene diatom species have disappeared (Fenner, 1985). In the Late Oligocene high-latitude Hemiaulus species spread far toward the equator (Fenner, 1984) corresponding to a reorganization of oceanic circulations.

Neogene diatom deposits were investigated all over the world both in land outcrops and in many deep-sea drilling cores in different oceans at low, middle and high latitudes. Therefore it is difficult to list here Hemiaulus occurrences from all around the world. It should be noted that Hemiaulus diversity continuously dropped through the Miocene and Pliocene, as already shown by Jousé (1978) in a diagram of evolutionary changes in the generic composition of marine diatoms. During the Neogene, Hemiaulus is listed among other genera related to littoral or neritic areas (e.g. Jousé, 1978; Monjanel, 1987; Pestrea et al., 2002).

There are only four extant species: Hemiaulus hauckii Grunow ex Van Heurck 1882 and H. sinensis Greville 1875 reported from warm to temperate waters and $H$. indicus Karsten 1907, and H. membranaceous Cleve 1873 from warm waters (Hasle and Syvertsen, 1997). Recent and present day Hemiaulus are known both from neritic (Hendey, 1964; Cupp, 1977; Guo, 1994; Sá et al., 2013) and pelagic open marine ecosystems (Villareal, 1991; Rivera et al., 2003; Kemp and Villareal, 2013; Anderson et al., 2018).

It should be noted that the genus Hemiaulus was not reassessed recently as was the case for instance for the genus Triceratium that was split into several genera. Further taxonomic studies might reveal that what currently is still referred to Hemiaulus might be in fact a group of several similar looking genera.

It seems that during a long geological time span Hemiaulus experienced some ecological changes implying the passage from neritic to more open oceanic environments. Adaptation to pelagic open marine ecosystems was possible for diatoms thanks to specificities such as symbioses with N2-fixing cyanobacteria (Foster et al., 2011). The presence of such a symbiosis, clearly identified for modern Hemiaulus (Villareal, 1991), has been interpreted as an adaptation of the diatoms to low-nutrient waters of the open ocean (Foster et al., 2011; Kemp and Villareal, 2013). This adaptation seems to have already been acquired in the Late Cretaceous since Hemiaulus blooms were identified by Davies and Kemp (2016) in Upper Cretaceous sequences from Alpha Ridge (Arctic Ocean, core CESAR 6) and Marca Shale (Moreno Formation, Califonia) corresponding to summer stratified conditions. Their obse- 
rvations are supported indirectly by isotopic evidence for $\mathrm{N}$ fixation (Meyers et al., 2009) and biomarker evidence for the presence of cyanobacteria (Kuypers et al., 2004; Wagner et al., 2004).

The long ranging Hemiaulus was witness to several steps in the long and complex diatom history. Some events are thought to be responses to environmental changes related to global palaeoceanographic conditions driven by global climate changes and tectonics (e.g. Barron and Baldauf, 1989; Sims et al., 2006; Harwood et al., 2007; Kooistra et al., 2007; Egan et al., 2013; Lazarus et al., 2014). Hemiaulus crossed the crucial boundary Cretaceous-Paleogene boundary being among the $84 \%$ of diatoms (estimation in Harwood, 1988) that did not suffer a major extinction. According to its species occurrences (see Strel'Nikova, 1975), Hemiaulus testifies to a latitudinal zonation of diatoms since the Late Cretaceous. Hemiaulus is among the genera that suffered a major shift in diversity that happened during the Oligocene. Indeed, many lineages known since the Cretaceous disappeared or became less common, whereas new taxa emerged or became more common (Kooistra et al., 2007). This new picture in diatom diversity is correlative with global changes (Sims et al., 2006). Beginning with the Cenozoic, the reorganization of the oceanic masses became more evident with the onset of Antarctic glaciations and deep-water cooling in the earliest Oligocene (Fenner, 1985; Scherer et al., 2000) and intensified during the Miocene and Pliocene, punctuated by several high-latitude cooling steps (Barron and Baldauf, 1989; Lazarus et al., 2014; Barron et al., 2015). So, Hemiaulus experienced life in a changing world, from a Cretaceous "green house" with a thermospheric circulation to a gradual development of the cryosphere with a thermohaline circulation reflecting the continuously installation of ice on Antarctica (Berggren and Prothero, 1992). The decline of the diversity of Hemiaulus from over 40 species in the Late Cretaceous (Harwood and Nikolaev, 1995) to only four extant species via an important drop in the Oligocene might be explained at least partially by a more global trend of lowering of water temperatures. Late Cretaceous global sea surface temperatures were estimated to be around $10^{\circ} \mathrm{C}$ warmer than today (De Conto et al., 2000). The Thai specimen shows that some long ranging genera registered in the early history of diatoms such as Hemiaulus were able to acclimatize and/or adapt through geological time to various conditions in the marine environment.

The discovery of Hemiaulus in Thai amber also raises questions about the initial palaeogeographic distribution of diatoms. Indeed, during the Jurassic-Early Cretaceous, all sites recording diatoms, including Hemiaulus, were situated on the southern coast of Laurasia. It is possible that early diatoms originated from the northern shore of the Tethys on which diatoms lived in shallow coastal waters. Such a hypothesis could be verified only with the discovery of new fossil diatoms from the Jurassic/Early Cretaceous (including amber deposits that demonstrated their potential for diatom preservation; Girard et al., 2009b).

Another palaeoecological implication related to the discovery of the oldest known occurrence of Hemiaulus from Thai amber concerns the hypothesis about the ancient habitats of early diatoms. According to Harwood et al. (2007) diatoms found in the Korean earliest Cretaceous would extend the confirmed presence of diatoms and suggest a continental habitat for early diatoms. The occurrence of the marine genus Hemiaulus from the Late Jurassic in the same geographical area obviously raises questions. It should be noted that no subsequent fossil record attests the occurrence of freshwater diatoms until the Late Cretaceous. The co-occurrence of marine and freshwater diatoms at the same time would therefore need to be confirmed. The record of Thai Hemiaulus is in agreement with the molecular data indicating that most of the extant basal lineages of diatoms are marine (Medlin and Kaczmarska, 2004). The discovery of the Thai specimen may revive the ever-recrurring question of whether the first diatoms were marine or freshwater. Hemiaulus is a typical marine genus and no species is known from brackish or freshwater environments, either in the fossil record or in present-day assemblages. The hypothesis of the invasions of freshwater environments by marine diatoms was invoked to explain the evolution of the diatom flora from marine taxa based on the record of fossil marine diatoms extending before those of freshwater forms (see citations in Sims et al., 2006). Among centric diatoms the example of Actinocyclus should be noted: it originated in marine environments that experienced a large diversification before moving into freshwaters (Bradbury and Krebs, 1995). The occurrence of Hemiaulus only in marine environments since its earliest known record from Thai amber (present work) agrees with the observation of Strel'Nikova and Lastivka (1999) that older centric diatom lineages failed to adapt to the lower salinity of inland waters, apart from the Early Cretaceous marine Archepyrgus that is considered by Harwood and Nikolaev (1995) as the ancestor of freshwater Aulacoseira.

Finally, any discovery of Pre-Cretaceous diatoms could potentially help to answer crucial questions about the palaeobiogeographical and environmental conditions in which diatoms emerge.

\section{Conclusions}

As for the angiosperms, Darwin could have described the origin of diatoms as "an abominable mystery". Although Thai amber does not solve this problem, it does provide new evidences about the early fossil record of diatoms and highlights that a probable pre-Cretaceous fossil record should exist. To judge from the oldest known diatom fossils, this fossil record should come from neritic shallow environments that developed along the northern shore of the Tethys. The fact that the oldest known diatom occurrence corresponds to Hemiaulus, a still extant genus, raises questions concerning diatom evolution: a) morphology of the frustules that is supposed to show evolutionary innovations already in the Late Jurassic allowing this genus to cross critical boundaries while other Early Cretaceous genera disappeared; b) insights on the early history of bipolar diatoms; c) information about the roots of "oldest" and "modern" lineage histories; d) adaptation/ acclimatization to changing marine environments (e.g. water stratification and anoxia, eutropic upwelling systems, diazotrophic conditions). Hemiaulus might be regarded as opening a path into the very long history of a marine genus: from the origin of diatoms in the marine environment marine to geographical expansion, high species diversification and then gradual decline. 


\section{Supplementary Material}

SOM Thermogravimetry.

The Supplementary Material is available at http://www.bsgf.fr/ $10.1051 / \mathrm{bsgf} / 2020028 / \mathrm{olm}$.

Acknowledgement. We thank M. Philippe and J. Le Loeuff for constructive discussion about the age of the material and N. Rowe for checking the usage of English. We thank also A. Giaretta (Padua, Italy) for thermal analysis of amber. We thank J. Witkowski for its kindly suggestions and a anonymous reviewer for its constructive comments. Material is housed in the collection of the Palaeontological Research and Education Centre, Maha Sarakham University (Thailand). For more information, please contact V. Suteethorn. This is publication $\mathrm{n}^{\mathrm{o}}$ ISEM 2020-175 SUD of the Institut des Sciences de l'Evolution de Montpellier (France).

\section{References}

Anderson EE, Wilson C, Knap, AH, Villareal T. 2018. Summer diatom blooms in theeastern North Pacific gyre investigated with a long-enduranceautonomous surface vehicle. Peer $J$ 6: e5387. https://doi.org/10.7717/peerj.5387.

Asama K, Nakornsri N, Hinthong C, Sinsakul S. 1981. Some younger Mesozoic plants from Trang, southern Thailand. Geology and Palaeontology of Southeast Asia 22: 35-47.

Baldauf JG. 1992. Middle Eocene through Early Miocene diatom floral turnover. In: Prothero DR, Berggren WA, eds. EoceneOligocene Climatic and Biotic Evolution. Princeton University Press, pp. 310-326.

Barron JA. 1985. Diatom biostratigraphy of the CESAR 6 core, Alpha Ridge. Initial Geological Report of CESAR-the Canadian Expedition to study the Alpha Ridge. Geological Survey of Canada Paper 84: 137-143.

Barron JA, Baldauf JG. 1989. Tertiary cooling steps and paleoproductivity as reflected by diatoms and biosiliceous sediments. In: Berger WH, Smetacek VS, Wefer G, eds. Productivity of the Ocean: Present and Past. John Wiley \& Sons Limited, pp. 341-354.

Barron JA, Baldauf JG. 1995. Cenozoic marine diatom stratigraphy and applications to paleoclimatology and paleoceanography. In: Blome CD, Whalen PM, Reed KM, eds. Siliceous microfossils. Paleontological Society Short Courses in Paleontology. Knoxville (USA): University of Tennessee, 8: 107-118.

Barron JA, Bukry D, Poore RZ. 1984. Correlation of the Middle Eocene Kellog Shale of northern California. Micropaleontology 30: 138-170.

Barron JA, Stickley CE, Bukry D. 2015. Paleoceanographic and paleoclimatic constraints on the global Eocene diatom and silicoflagellate record. Palaeogeography, Palaeoclimatology, Palaeoecology 422: 85-100.

Benda L. 1972. The diatoms of the Moler Formation of Denmark (Lower Eocene): a preliminary report. Nova Hedwigia Beihefte 39: 251-266.

Berggren WA, Prothero DR. 1992. Eocene-Oligocene climatic and biotic evolution: an review. In: Prothero D, Berggren WA, eds. Eocene-Oligocene Climatic and Biotic Evolution. Princeton University Press, pp. 1-28.

Bowler C, Allen AE, Badger JH, Grimwood J, Jabbari K, Kuo A, et al. 2008. The Phaeodactylum genome reveals the evolutionary history of diatom genomes. Nature 456: 239-244.
Bradbury JP, Krebs WN. 1995. Fossil continental diatoms: paleolimnology, evolution and biochronology. In: Babcock LE, Ausich WI, eds. Siliceous microfossils. Short Courses in Paleontology, The Paleontological Society. Knoxville, Tennesse, 8: 119-138.

Buffetaut E, Suteethorn V, Tong H, Köšir A. 2005. First dinosaur from the Shan-Thai block of SE Asia: a Jurassic sauropod from the southern peninsula of Thailand. Journal of the Geological Society London 162: 481-484.

Chacón-Baca E, Beraldi-Campesi H, Cevallos-Ferriz SRS, Knoll AH, Golubic S. 2002. 70 Ma nonmarine diatoms from northern Mexico. Geology 30: 279-281.

Chang KH, Bak YS, Park SO. 2007. Early Cretaceous diatoms and geology in Korea. Journal of the Paleontological Society of Korea 23: 205-212.

Chongllakmani C, Duan W. 1990. Note on the continental deposits of peninsular Thailand with a description of some conchostreans. Oil and Gas Geology 2: 31-37.

Cuny G, Srisuk P, Khamha S, Suteethorn V, Tong H. 2009. A new elasmobranch fauna from the Middle Jurassic of southern Thailand. Geological Society, London, Special Publications 315: 95-111.

Cuny G, Liard R, Deesri U, Liard T, Khamha S, Suteethorn V. 2014. Shark faunas from the Late Jurassic-Early Cretaceous of northeastern Thailand. Paläontologische Zeitschrift 88: 309-328.

Cupp EE. 1977. Marine plankton diatoms of the west coast of North America. Bulletin of the Scripps Institution of Oceanography of the University of California, La Jolla, California 5: $1-238$.

Davies A, Kemp AES. 2016. Late Cretaceous seasonal palaeoclimatology and diatom palaeoecology from laminated sediments. Cretaceous Research 65: 82-111.

De Conto RM, Brady EC, Bergengren J, Hay WW. 2000. Late Cretaceous climate, vegetation, and ocean interactions. In: Huber B, Macleod KG, Wing SL, eds. Warm climates in earth history. Cambridge: Cambridge University Press, pp. 275-296.

Dell'Agnese DJ, Clark DL. 1994. Siliceous microfossils from the warm late Cretaceous and early Arctic Ocean. Journal of Paleontology 68(1): 31-47.

Dörfelt H, Schäfer U. 2000. Palaeozygnema spiralis, ein Vertreter der Conjugatophyceae in mezozoischen Bernstein aus Bayern. Hoppea, Denkschriften der Regensburgischen Botanischen Gesellschaft 61: 785-793.

Edwards AR. 1991. The Oamaru diatomite. New Zealand Geological Survey Paleontological Bulletin 64: 260.

Egan KE, Rickaby REM, Hendry KR, Halliday AN. 2013. Opening the gateways for diatoms primes Earth for Antarctic galaciation. Earth and Planetary Sciences Letters 375: 34-43.

Falkowski PG, Katz ME, Knoll AH, Quigg A, Raven JA, Schofield O, et al. 2004. The evolution of modern eukaryotic phytoplankton. Science 305: 354-360.

Fenner J. 1984. Middle Eocene to Oligocene planktonic diatom stratigraphy from Deep Sea Drilling sites in the South Atlantic, Equatorial Pacific and Indian oceans. In: Hay WW, Sibuet JC, et al., eds. Initial Reports DSDP 75, Part 2. Washington, pp. 1245-1272.

Fenner J. 1985. Late Cretaceous to Oligocene planktic diatoms. In: Bolli HM, Saunders J, Perch-Nielsen K, eds. Plankton Stratigraphy. Cambridge University Press, pp. 713-762.

Fenner J. 1988. Occurrence of pre-Quaternary diatoms in Scandinavia reconsidered. Meyniana 40:133-141. 
Fenner J. 1994. Diatoms of the Fur Formation, their taxonomy and biostratigraphic interpretation-results from the Harre borehole, Denmark. Aarhus Geoscience 1: 99-131.

Fontaine H. 1990. The Upper Palaeozoic and Mesozoic fossils of West Thailand. In: Fontaine H, ed. Ten years of CCOP research on the Tertiary of East Asia. Bangkok (Tahiland): CCOP Technical Secretariat, pp. 353-357.

Forti A, Schulz P. 1932. Erste Mitteilung über Diatomeen aus dem Hannoverschen Gault. Beihefte zum Botanischen Zentralblatt 50: 241-246.

Foster RA, Kuypers MMM, Vagner T, Paerl RW, Musat N, Zehr JP. 2011. Nitrogen fixation and transfer in open ocean diatomcyanobacterial symbioses. The ISME Journal 5: 1484-1493.

Foucault A, Servant-Vildary S, Fang N, Powichrowski L. 1986. Un des plus vieux gisements de diatomées découvert dans l'AlbienCénomanien des Alpes-Ligures (Italie). Remarques sur l'apparition de ces algues. Comptes Rendus de l'Académie des Sciences 303: 397-402.

Fourtanier E. 1991a. Diatom biostratigraphy of equatorial Indian Ocean site 758. In: Weissel J, Peirce J, Taylor E, Alt J, et al., eds. Proceedings of the Ocean Drilling Program, Scientific Results 121: 189-208.

Fourtanier E. 1991b. Paleocene and Eocene diatom biostratigraphy and taxonomy of eastern Indian Ocean site 752. In: Weissel J, Peirce J, Taylor E, Alt J, et al., eds. Proceedings of the Ocean Drilling Program Scientific Results 121: 171-187.

Georgi KH. 1976. Mikrofaunistische-lithologische Untersuchungen der Hilssandstein-Region (Apt/Alb) im Raum Salzgitter-Gotlar. Mitteilungen aus dem Geologischen Institut der Technischen Universität, Hannover 13: 5-112.

Gersonde R, Harwood DM. 1990. Lower Cretaceous diatoms from ODP Leg 113 site 693 (Weddell sea). Part 1: Vegetative cells. In: Barker PF, et al., eds. Proceedings of the Ocean Drilling Program, Scientific Results. College Station, TX (Ocean Drilling Program), pp. 365-402.

Girard V. 2010. Microcénoses des ambres médio-crétacés français. Taphonomie, systématique, paléoécologie et reconstitution du paléoenvironnement. Mémoires Géosciences Rennes 134: 1-293.

Girard V, Schmidt AR, Saint Martin S, Struwe S, Perrichot V, Saint Martin JP, et al. 2008. Evidence for marine microfossils from amber. Proceedings of the National Academy of Sciences of the United States of America 105: 17426-17429.

Girard V, Néraudeau D, Breton G, Saint Martin S, Saint Martin JP. 2009a. Contamination of amber samples by recent microorganisms and remediation evidenced by Mid-Cretaceous amber of France. Geomicrobiology Journal 26: 21-30.

Girard V, Saint Martin S, Saint Martin JP, Schmidt AR, Struwe S, Perrichot V, et al. 2009b. Exceptional preservation of marine diatoms in Upper Albian amber. Geology 37: 83-86.

Girard V, Néraudeau D, Adl SM, Breton G. 2011. Protist-like inclusions in amber, as evidenced by Charentes amber. European Journal of Protistology 47: 59-66.

Girard V, Salpeteur I, Dutta S, Bauer H, Raju SV. 2014. An enigmatic piece of amber in the Oligocene of the Assam-Arakan basin (Eastern India). Geobios 48: 1-8.

Guiry MD, Guiry GM. 2020. AlgaeBase. World-wide electronic publication. Galway: National University of Ireland. http://www. algaebase.org.

Guo YI. 1994. Primary productivity and phytoplankton in China seas. In: Zhou D, Liang YB, Zeng CK, eds. Oceanology of China Seas. Dordrecht (The Netherlands): Kluwer Academic Publishers 1: 227-242.
Hajos M, Stradner H. 1975. Late Cretaceous archaemonadaceae, diatomaceae and silicoflagellate from the South Pacific Ocean. Deep Sea Drilling Project, Leg 29, site 275. In: Kennett JP, et al., eds. Initial Reports of DSDP 29. Washington, D.C., pp. 913-1009.

Hanna GD. 1927. Cretaceous diatoms from California. California Academy of Science, Occasional Paper 13: 1-49.

Harwood DM. 1988. Upper Cretaceous and Lower Paleocene diatom and silicoflagellates biostratigraphy of Seymour Island, eastern Antarctic Peninsula. Geological Society of America Memoir 169: 55-129.

Harwood DM, Gersonde R. 1990. Lower Cretaceous diatoms from ODP Leg 113 site 693 (Weddell sea). Part 2: resting spores, chrysophycean cysts, an endoskeletal dinoflagellate, and notes on the origin of diatoms. In: Barker PF, et al., eds. Proceedings of the Ocean Drilling Program, Scientific Results. College Station, TX (Ocean Drilling Program), pp. 403-426.

Harwood DM, Nikolaev VA. 1995. Cretaceous diatoms: morphology, taxonomy, biostratigraphy. In: Blome CD, et al. (convenors), Siliceous Microfossils. Paleontological Society Short Courses in Paleontology 8, 81-106

Harwood DM, Nikolaev VA, Winter DM. 2007. Cretaceous records of diatom evolution, radiation, and expansion. Paleontological Society Papers 13: 33-59.

Hasle G, Syvertsen EE. 1997. Marine diatoms. In: Tomas CR, ed. Identifying marine phytoplankton. USA: Academic Press, pp. 5386.

Heiberg PAC. 1863. Conspectus criticus diatomacearum danicarum. Kritisk oversigt over de danske Diatomeer, 6 pls. Kjøbenhavn: Wilhelm Priors Forlag, pp. 1-135.

Hendey NI. 1964. An introductory account of the smaller algae of British coastal waters. Part V. Bacillariophyceae (Diatoms). Fishery investigations, Series IV. Her Majesty's Stationery Office 1-317.

Homann M. 1991. Die Diatomeen der Fur-Formation (Alttertiär) aus dem Limfjord-Gebiet, Nordjütland/Dänemark. Geologisches Jahrbuch Reihe A 123: 285.

Jewson DH, Harwood DM. 2017. Diatom life cycles and ecology in the Cretaceous. Journal of Phycology 53: 616-628.

Jousé A. 1949. New upper Cretaceous diatoms and silicoflagellates from argillaceous sands and the Bol'shoi Kitoi river, east slope of the northern Ural. Botaniceskie Materialy Otdela Sporovyh Rastenij Botaniceskogo Instituta Imeni V.L. Komarova Akademii Nauk SSSR 6: 1-6.

Jousé A. 1978. Diatom biostratigraphy on the generic level. Micropaleontology 24(3): 316-326.

Kanjanapayont P. 2014. Deformation style of the Mesozoic sedimentary rocks in southern Thailand. Journal of Asian Earth Sciences 92: 1-9.

Kemp AES, Villareal TA. 2013 High diatom production and export in stratified waters - a potential negative feedback to global warming. Progress in Oceanography 119: 4-23.

Kemper E, Bertran H, Deiters H. 1975. Zur Biostratigraphie und Paleokölogie der Schichtenfolge Ober Apt/Unter imm Beckenzeirum nördlich und östlich von Hannover. Berichte der Naturhistorischen Gesellschaft Hannover 119: 49-85.

Kooistra WCF, Gersonde R, Medlin LK, Mann DG. 2007. The origin and evolution of the diatoms: their adaptation to a planktonic existence. In: Falkowski PG, Knoll AH, eds. Evolution of primary producers in the sea. Burlington (USA): Elsevier Academic Press, pp. 201-250.

Kuypers MMM, van Breugel Y, Schouten S, Erba E, Damste JSS. 2004. N2-fixing cyanobacteria supplied nutrient $\mathrm{N}$ for Cretaceous oceanic anoxic events. Geology 32(10): 853-856. 
Lazarus D, Barron J, Renaudie J, Diver P, Turke A. 2014. Cenozoic planktonic marine diatom diversity and correlation to climate change. Plos One 9(1), https://doi.org/10.1371/journal. pone.0084857.g001.

Lei Z. 1993. The discovery and significance of the Late Jurassic sporopollen assemblage in peninsular Thailand. In: Thanasuthipitak T, ed. Biostratigraphy of Mainland Southeast Asia: Facies and Paleontology. Chiang Mai (Thailand): Chiang Mai University, pp. 361-379.

Martin JE, Deesri U, Liard R, Wattanapituksakul A, Suteethorn S, Lauprasert K, et al. 2016. Strontium isotopes and the long-term residency of thalattosuchians in the freshwater environment. Paleobiology 42(1): 143-156.

Martin J, Suteethorn S, Lauprasert K, Tong H, Buffetaut E, Liard R, et al. 2019. A new freshwater teleosaurid from the Jurassic of northeastern Thailand. Journal of Vertebrate Paleontology. https:// doi.org/10.1080/02724634.2018.1549059.

Martín-González A, Wierzchos J, Gutièrrez JC, Alonso J, Ascaso C. 2008. Morphological stasis of protists in Lower Cretaceous amber. Protist 159: 251-257.

McCartney K, Witkowski J, Harwood DM. 2014. New insights into skeletal morphology of the oldest known silicoflagellates: Variramus, Cornua and Gleserocha gen. nov. Revue de Micropaléontologie 57: 75-91.

Medlin LK. 2010. A timescale for diatom evolution based on four molecular markers and assigning off ghost lineages to original discoverers. Abstracts of the 21st International Diatom Symposium, Minneapolis, $35 \mathrm{p}$.

Medlin LK. 2011. A review of the evolution of the diatoms from the origin of the lineage to their populations. In: Seckbach J, Kociolek JP, eds. The diatom world. Amsterdam: Springer, pp. 95-118.

Medlin LK, Kaczmarska I. 2004. Evolution of the diatoms: V. Morphological and cytological support for the major clades and a taxonomic revision. Phycologia 43: 245-270.

Meesook A, Saengsrichan W. 2011. Jurassic. In: Ridd MF, Barber AJ, Crow MJ, eds. The geology of Thailand. London (United Kingdoms): The Geological Society of London, pp. 151-168.

Meyers PA, Bernsconi SM, Yum JG. 2009. 20 My nitrogen fixation during deposition of mid-Cretaceous black shales on the Demerara Rise, equatorial Atlantic Ocean. Organic Geochemistry 40: 158-166.

Monjanel A-L. 1987. Les diatomées oligocènes à holocènes de l'Atlantique nord rt de la Méditerranée occidentale. Thèse de doctorat de 1'Université de Bretagne occidentale, Brest, Nouvelle série $38,320 \mathrm{p}$.

Nakov T, Beaulieu JM, Alverson AJ. 2018. Accelerated diversification is related to life history and locomotion in a hyperdiverse lineage of microbial eukaryotes (Diatoms, Bacillariophyta). New Phytologist 219: 462-473.

Nikolaev VA, Kociolek JP, Fourtanier E, Barron JA, Harwood DM. 2001. Late Cretaceous diatoms (Bacillariophyceae) from the Marca Shale member of the Moreno Formation (California). Occasional Papers of the Clifornia Academy of Sciences 152: 119.

Nohra Y, Azar D, Gèze R, Maksoud S, El-Samrani A, Perrichot V. 2013. New Jurassic amber outcrops from Lebanon. Terrestrial Arthropod Reviews 6: 27-51.

Oreshkina TV, Radionova EP. 2014. Diatom record of the PaleoceneEocene Thermal Maximum in marine paleobasins of Central Russia, Transuralia and adjacent regions. Nova Hedwigia, Beiheft, 143: 307-336.

Oreshkina TV, Lygina EA, Vozhzhiva OA, Ivanov AV. 2013. Diatoms and silicoflagellates of the Upper Cretaceous from Saratov region: biostratigraphy and sedimentation settings. Stratigraphy and Geological Correlation 21: 222-236.
Pestrea S, Blanc-Valleron MM, Rouchy JM. 2002. Les assemblages de diatomées des niveaux infra-gypseux du Messinien de Méditerranée (Espagne, Sicile, Chypre). In: Néraudeau D, Goubert E, eds. L'Événement messinien: approches paléobiologiques et paléoécologiques. Geodiversitas 24(3): 543-583.

Philippe M, Cuny G, Suteethorn V, Teerarungsigul N, Barale G, Thevenard F, et al. 2005. A Jurassic amber deposit in Southern Thailand. Historical Biology 17: 1-6.

Poinar G Jr, Waggoner BM, Bauer UC. 1993a. Terrestrial soft-bodies protists and other micro-organisms in Triassic amber. Science 259: 222-224.

Poinar G Jr, Waggoner BM, Bauer UC. 1993b. Description and palaeoecology of a Triassic amoeba. Naturwissenschaften 80:566-568.

Racey A, Goodall JGS. 2009. Palynology and stratigraphy of the Mesozoic Khorat Group red bed sequences from Thailand. Geological Society, London, Special Publications 315: 69-83.

Ragazzi E, Roghi G, Giaretta A, Gianolla P. 2003. Classification of amber based on thermal analysis. Thermochimica Acta 404: 43-54.

Ragazzi E, Giaretta A, Perrichot V, Néraudeau D, Schmidt AR, Roghi G. 2009. Thermal analysis of Cretaceous ambers from southern France. Geodiversitas 31: 163-175.

Renaudie J, Drews EL, Bohne S. 2018. The Paleocene record of marine diatoms in deep-sea sediments. Fossil Record 21, 183-205.

Rivera P, Avaria S, Cruces F. 2003. La familia Hemiaulaceae (Bacillariophyceae) de las aguas marinas chilenas. Revista Chilena de Historia Natural 76: 651-664.

Roghi G, Ragazzi E, Gianolla P. 2006. Triassic amber of the Southern Alps (Italy). Palaios 21: 143-154.

Roghi G, Kustatscher E, Ragazzi E, Giusberti L. 2017. Middle Triassic amber associated with Voltzialean conifers from the Southern Alps of Italy. Rivista italiana di paleontologia $e$ stratigrafia 123: 193-201.

Ross R. 1995. A revision of Rutilaria Greville (Bacillariophyta). Bull. Brit. Mus. (Nat. Hist.), Botany Series 25: 1-93.

Round FE, Crawford RM, Mann DG. 1990. The diatoms biology and morphology of the genera. pp. [i-ix], 1-747. Cambridge: Cambridge University Press.

Rothpletz A. 1896. Über die Flysch-Fucoiden und einige andere fossile Algen, sowie über liasische, Diatomeen führende Hornschwämme. Zeitschrift der Deutsche Geologische Gesellschaft 48: 910-914.

Rothpletz A. 1900. Über einen neuen jurassichen Hornschwämme und die darin eingeschlossenen Diatomeen. Zeitschrift der Deutsche Geologische Gesellschaft 52: 154-160.

Rüst D. 1885. Beitrage zur Kenntris der fossilen Radiolarien aus Gestenien der Jura. Palaeontographica 31: 273-321.

Sá C, Leal MC, Silva A, Nordez S, André E, Paula J, et al. 2013. Variation of phytoplankton assemblages along the Mozambique coast as revealed by HPLC and microscopy. Journal of Sea Research 79: 1-11.

Saengsrichan W, Charoentitirat T, Meesook A, Hisada K-I, Charusiri P. 2011. Paleo-environments and tectonic setting of the Mesozoic Thung Yai Group in Peninsuler Thailand, with a new record of Parvamussium donaiense Mansuy, 1914. Gondwana Research 19: 47-60.

Saint Martin S, Saint Martin JP. 2018. Exquisite preservation of a widespread filamentous microorganism from French Cretaceous ambers: a key for review of controversial fossil. Comptes Rendus Palevol 17: 415-434.

Saint Martin S, Saint Martin JP, Schmidt AR, Girard V, Néraudeau D, Perrichot V. 2015. The intriguing marine diatom genus Corethron in Late Cretaceous amber from Vendée (France). Cretaceous Research 52: 64-72. 
Sato S. 2008. Phylogeny of araphid diatoms, inferred from morphological and molecular data. PhD Dissertation, University of Bremen. http//elib.suub.uni-bremen.de/diss/docs/00011057.pdf.

Scherer R, Bohaty SM, Harwood DM. 2000. Oligocene and Lower Miocene Siliceous Microfossil Biostratigraphy of Cape Roberts Project Core CRP-2/2A, Victoria Land Basin, Antarctica. Terra Antartica 7(4): 417-442.

Schmidt AR, Schönborn W, Schäfer U. 2004. Diverse fossil amoebae in German Mesozoic amber. Palaeontology 47:185-197.

Schönborn W, Dörfelt H, Foissner W, Krienitz L, Schäfer U. 1999. A fossilized microcenosis in Triassic amber. Journal of Eukaryotic Microbiology 46: 571-584.

Schrader HJ, Fenner J. 1976. Norwegian sea diatom biostratigraphy and taxonomy. In: Talwani M, Udintsev $\mathrm{G}$, et al., eds. Initial Reports DSDP 38. Washington, pp. 921-1098.

Seyfullah LJ, Beimforde C, Dal Corso J, Perrichot V, Rikkinen J, Schmidt AR. 2018. Production and preservation of resins - past and present. Biological Reviews 93: 1684-1714.

Sims PA, Mann DG, Medlin LK. 2006. Evolution of diatoms: insights from fossil, biological and molecular data. Phycologia 45:361-402.

Smetacek V. 1999. Diatoms and the ocean carbon cycle. Protist 150: $25-32$.

Sorhannus U. 2007. A nuclear-encoded small-subunit ribosomal RNA timescale for diatom evolution. Marine Micropaleontology 65: $1-12$.

Strel'Nikova NI. 1975. Diatoms of the Cretaceous period. Nova Hedwigia Beiheft 53:311-321.

Strel'Nikova NI, Lastivka TV. 1999. The problem of the origin of marine and freshwater diatoms. In: Simola H, ed. Proceedings of 14th International Diatom Symposium, Koeltz Scientific Books, Koenigstein, pp. 195-204.

Strel'Nikova NI., Martirosjan GN. 1981. Lower diatom algae from Stavropol. Viestnik LGU, Ser. Biologiya 3:52-57.

Suteethorn S, Le Loeuff J, Buffetaut E, Suteethorn V, Wongko K. 2012. First evidence of a mamenchisaurid dinosaur from the Upper Jurassic-Lower Cretaceous Phu Kradung Formation of Thailand. Acta Palaeontologica Polonica 58(3): 459-469.
Tapia PM, Harwood DM. 2002. Upper Cretaceous diatom biostratigraphy of the Arctic archipelago and northern continental margin, Canada. Micropaleontology 48: 303-342.

Teerarungsigul N, Raksaskulwong L, Khantaprab C. 1999. Reconsideration of lithostratigraphy of non-marine Mesozoic rocks in Thung Yai-Khlong Thom area, Southern Thailand. In: Khantraprab C, Sarapirome S, eds. Proceedings of the Symposium on Mineral, Energy and Water Resources of Thailand: Towards the Year 2000. Bangkok (Thailand): Department of Mineral Resources, pp. 109-114.

Tréguer P, Nelson D, van Bennekom AJ, DeMaster DJ, Leynaert A. 1995. The silica balance in the world ocean: a reestimate. Science 268: 375-379.

Vakhrameev VA. 1987. Climates and the distribution of some gymnosperms in Asia during the Jurassic and Cretaceous. Review of Palaeobotany and Palynology 51: 205-2112.

Villareal TA. 1991. Nitrogen-fixation by the cyanobacterial symbiont of the diatom genus Hemiaulus. Marine Ecology Progress Series 76: 201-204.

Wagner T, Damste JSS, Hofmann P, Beckmann B. 2004. Euxinia and primary production in Late Cretaceous eastern equatorial Atlantic surface waters fostered orbitally driven formation of marine black shales. Paleoceanography 19(4): 3009. https://doi.org/10.1029/ 2003PA000898.

Wall JH. 1975. Diatoms and radiolarians from the Cretaceous system of Alberta - a preliminary report. Geological Association of Canada, Special Papers 13: 391-409.

Witkowski J, Harwood DM, Chin K. 2011. Taxonomic composition, paleoecology and biostratigraphy of Late Cretaceous diatoms from Devon Island, Nunavut, Canadian High Arctic. Cretaceous Research 32: 277-300.

Wornardt WW Jr. 1972. Stratigraphic distribution of diatom genera in marine sediments in Western North America. Palaeogeography, Palaeoclimatology, Palaeoecology 12: 49-74.

Yu T, Kelly R, Mu L, Ross A, Kennedy J, Broly P, et al. 2019. An ammonite trapped in Burmese amber. Proceedings of the National Academy of Sciences of the United States of America 116: 11345-11350.

Cite this article as: Girard V, Saint Martin S, Buffetaut E, Saint Martin J-P, Néraudeau D, Peyrot D, Roghi G, Ragazzi E, Suteethorn V. 2020. Thai amber: insights into early diatom history? BSGF - Earth Sciences Bulletin 191: 23. 